\title{
Which Corporate Governance Mechanisms Drive CSR Disclosure Practices in Emerging Countries?
}

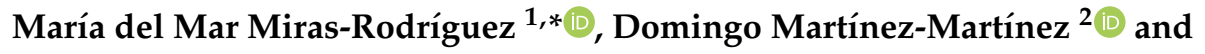 \\ Bernabé Escobar-Pérez ${ }^{3}$ \\ 1 Department of Financial Economics and Operation Management, Universidad de Sevilla, \\ 41018 Seville, Spain \\ 2 Department of Financial Economics and Accounting, Universidad de Cádiz, 11002 Cadiz, Spain; \\ domingo.martinez@uca.es \\ 3 Department of Accounting and Financial Economics, Universidad de Sevilla, 41018 Seville, Spain; \\ bescobar@us.es \\ * Correspondence: mmiras@us.es
}

Received: 18 November 2018; Accepted: 19 December 2018; Published: 22 December 2018

\begin{abstract}
Although several studies have analyzed the role that specific corporate governance mechanisms have on Corporate Social Responsibility (CSR) reporting practices, their findings have not been conclusive and the evidence from developing countries is scarce. The theoretical support for this relationship in the previous literature is found in Stakeholder, Agency, Legitimacy, and Good Management theories. Undoubtedly, as the institutional environment has an important impact on CSR reporting practices, it would be relevant for this field of research to analyze this relationship in companies from emerging countries. It is suggested for the sake of convenience to consider different levels of corporate governance mechanisms together due to the high interdependence among them. Consequently, the aim of this paper is to analyze whether different levels of corporate governance mechanisms (at the institutional, group, and firm level) are determinant factors of the CSR reporting practices in BRICS countries (Brazil, Russia, India, China, and South Africa). The final sample was composed of 281 companies. On the basis of our results, we conclude that institutional corporate governance mechanisms influence the company's CSR reporting strategy and that both CSR disclosure practices analyzed are affected by group-level corporate governance mechanisms in companies from family-based societies. Our findings support the appropriateness of separately analyzing this issue in emerging countries.
\end{abstract}

Keywords: CSR reporting practices; Institutional Theory; corporate governance; BRICS

\section{Introduction}

Due to the large number of cases of negligence, corruption, and bad praxis uncovered over the last 10 years and their significant impact from an economic, social, and environmental perspective, Corporate Social Responsibility (CSR) is receiving increasingly more attention from academics, professionals, and society in general [1]. Inevitably, incidents of corporate fraud and scandals such as the Volkswagen or Shell cases have promoted the idea that current corporate governance needs to adopt an ethical, accountable, and socially responsible agenda in addition to dealing with agency conflicts [2].

In this sense, what is happening in organizations is going to be known-particularly if it is not a good practice-due to the power of social media. As a result, it falls to companies to decide whether they want to have a proactive role in the reporting of this kind of information which goes further than mandatory reporting [3]. 
For several years, companies have been aware of the relevance of reporting their socially responsible performance to stakeholders because this reduces informational asymmetries $[4,5]$ and increases transparency [6]. In order to accomplish this task through a report, firms have mainly three options [7]: an integrated report (following International Integrated Reporting Council recommendations); an annual report in which CSR information is included; or an independent CSR/sustainability report. Although in recent years there has been growing interest in integrated reports [8], most corporations communicate their CSR behaviors through a specific CSR/sustainability report or include the CSR information in their annual report [9].

To be a successful, socially responsible enterprise, CSR actions must be correctly communicated and have public visibility. For this reason, many scholars have emphasized the importance of these reports being perceived as credible [10,11]. In order to enhance the quality of the reports, several steps have been taken in two directions: the homogeneity of the reports (through international standards such as Global Reporting Initiative-GRI-) and the verification of the information disclosed (assurance).

The previous literature identifies company size, profitability, industry, and financial performance as determinants of CSR reporting [12-14]. More recently, studies have also highlighted the effect that certain corporate governance (CG) mechanisms have on the existence and extension of CSR reports $[15,16]$. The relationship between CG mechanisms and CSR reporting has progressively attracted the interest of academics [17-19]. This suggests the appropriateness of going further into the study of CG mechanisms as determinants of CSR reporting.

Most of these articles analyze this relationship from a one-level approach, although some researchers [20] recommended studying this question from a multi-level approach in order to be able to identify interdependences between multiple mechanisms. For these two authors, some of the CG variables selected by researchers as determinants of social performance are often interrelated and can have a compound effect despite belonging to different corporate levels (institutional, firm, group, or individual levels).

This paper goes further in this line of research, though it is focused on a context which has received less attention from academia [21] - emerging countries. Differences with other, more developed environments [22] are expected due to: (1) the impact of the contextual and political factors on CSR reporting strategies [23], particularly because there is less pressure from the public concerning CSR disclosure in BRICS countries (Brazil, Russia, India, China, and South Africa) [14], and (2) CG mechanisms are less effective if a country's governance system is not as strong as it should be [24]. Moreover, the roles of the board of directors' members could differ when they are compared with those of other, more developed countries [25].

Based on the information of CSR reports from the companies of emerging countries, the aim of this study is to analyze how different levels of CG mechanisms affect companies' CSR reporting strategies in the context of emerging countries.

Considering these arguments, the study focuses on companies from BRICS nations (Brazil, Russia, India, China, and South Africa). Due to the data availability, the final sample is composed of 281 companies. Furthermore, this research is original in providing an analysis of corporate commitment to CSR reporting across BRICS nations.

The rest of this paper is organized as follows. The next section reviews the main theoretical approaches identified in the literature on the CSR reporting field. Then, from the identification of the determinants most used in previous research and considering the multi-level approach of CG mechanisms, three hypotheses are formulated. In the following section, information about the method and the sample is provided. Finally, the results are presented and some conclusions are drawn.

\section{Determinants of CSR Reporting and Hypotheses Development}

The literature focused on the analysis of the explanatory factors that affect CSR or sustainability reporting has pointed out that company size [13], financial performance [26,27], industry [28], and cultural environment [29] are determinants of CSR disclosure practices. In this sense, the pressures 
faced by companies as a consequence of the context in which they operate is revealed to be a key variable which allows a better understanding of their CSR reporting practices. In fact, most researchers recommend studying such variables by centering on a group of countries with similarities due to the difficulty of isolating or controlling their effects $[23,30]$.

Research on this topic has usually been focused on developed countries, although some recent research has centered on emerging countries $[14,19,22]$. In this sense, most of the published research works analyze whether these traditional determinants of CSR reporting practices are also a relevant explanation in emerging countries. As a result, we highlight that there are not significant differences in the impact of these traditional determinants (size, financial performance, industry, and cultural environment) of CSR reporting practices between developed or developing countries. That is, in general, larger and more profitable companies and those which operate in environmentally sensitive industries show a greater commitment to non-financial disclosures, regardless of the cultural environment.

What is more, the role of regulation - the existence of a law that makes the adoption of certain CSR reporting practices mandatory [31] —as well as the company's level of internationalization are presented as key variables for explaining the adoption of a CSR reporting practice, particularly in emerging countries [32,33]. That is, regulation is usually a driver of CSR disclosure particularly in the environment of emerging markets where this kind of practice is avoided by companies unless it is a requirement (Baskin, 2006). Internationalization is presented as another pressure for the adoption of CSR reporting practices. If companies want to operate globally, they need to meet the formal and the informal requirements in all markets, and in the majority of developed countries' markets CSR is no longer optional.

In addition to the corporate features discussed above, the corporate governance-social responsibility nexus has recently received a great deal of attention. In fact, it could be stated that the scope of CG has broadened to encompass the growing importance of CSR [11]. Irrespective of the theoretical reasons, most research reveals that CG mechanisms influence the nature and extent of CSR reporting [34,35]. Ntim and Soobaroyen [36] claimed that better governed corporations tend to pursue a more socially responsible agenda through increased CSR practices.

In order to empirically support this relationship, several authors have analyzing how corporate governance attributes are individually associated with different CSR reporting issues [19,22]. However, Aguilera et al. [37] argued that CG variables are commonly examined separately according to the level of analysis at which they operate. These are interdependent and interact with and affect both financial and social outcomes in tandem. In this regard, Jain and Jamali [20] performed a literature review in which they identified how different levels of CG mechanisms (institutional, firm, group, and individual) impacted CSR. In the light of their findings, they encouraged scholars to "espouse a holistic approach where mechanisms associated with different levels of CG are seen as interacting, i.e., substituting, complementing, or overriding others, to form bundles and configurations of governance practices that in turn influence CSR outcomes" (p. 266). This novel perspective for CG-CSR research, along with the opportunity to elucidate CSR reporting in BRICS nations, leads us to propose our hypotheses, considering the different theoretical arguments that support each relationship.

\subsection{Institutional-Level CG Mechanisms}

In order to show the relevance of the institutional environment in corporate reporting, we found theoretical support in Institutional Theory [38-40], Stakeholders Theory [41,42], and Legitimacy Theory [43]. According to Ali et al. [14], this last theoretical approach (Legitimacy Theory) is the dominant theoretical lens in studies of companies from both developed and developing countries.

Companies are pressured by the environment in which they compete to adopt certain CSR disclosure practices in order to be competitive in the market $[29,44]$. In addition to responding to social pressures and contributing to their social legitimation, CSR reports are also essential to satisfy institutional pressures [45]. Aguilera and Jackson [46] pointed out the special usefulness of this approach to try to explain the way that corporate governments have to fulfill their functions. 
CSR disclosure is one manner of doing so. Pressures surrounding companies lead them to adopt similar behaviors over time, since organizations recognize the characteristics of their legal, cultural, and societal environment in order to conform to the prevalent rules, norms, and routines [38].

Luoma and Goodstein [47] emphasized the need to understand the institutional environment in which firms operate for a better comprehension of firm strategies and managerial choices in relation to CSR practices and engagement. Following this suggestion, some authors have shown how the differences concerning CSR implementation and performance among organizations from different institutional settings can be explained in terms of the differences in the rules, norms, values, routines, and responsibilities expected [40]. Likewise, CG mechanisms are determined by the institutional environment in which each company has developed its activities [19,30]. Jain and Jamali [20] distinguished between formal and informal institutional mechanisms. According to their findings, authors interested in the effect of these mechanisms should explore them together. While formal ones comprise two important aspects for managerial discretion - the nature of the political and legal system and the existence of CG regulations-the second type of mechanism refers to the norms, values, and culture at the country level.

Chiu and Wang [48] identified the different roles of firms and stakeholders in each society as a cornerstone for a better comprehension of the extent, issues, and quality of CSR reporting. Thus, even when companies under study come from countries which share distinctive economical features, the way in which they address and communicate their CSR actions could be subjected to effects of different institutional environments and governance styles $[49,50]$.

Consequently, our first hypothesis states:

Hypothesis 1 (H1): Institutional-level CG mechanisms are determinants of the CSR disclosure practices in BRICS countries.

\subsection{Firm-Level CG Mechanisms}

Ownership structure has been the most recurrent CG mechanism examined as a determinant of CSR reporting at the firm level, especially in developed countries [22,51-53]. Most research conducted so far has considered CSR reporting to be an additional component associated with voluntary corporate disclosure. Precisely, its novel and non-compulsory character has been responsible from its origins for potential conflicts of interest between shareholders and managers. In accordance with Agency Theory assumptions, it is supposed that the main shareholders have both greater power and incentives to monitor management, as their wealth is tied to the firm's financial performance [54]. Regarding the number of shareholders, opportunistic management behavior and conflicts of interests between the principal and the agent are normally associated with high dispersion ownership [26,55]. When ownership is dispersed across many investors, there is increased pressure on managers and they are expected to disclose more information in order to gain legitimacy and reduce the agency costs of monitoring activities $[50,56]$. From this perspective, corporate disclosures become a helpful tool to improve the monitoring function in companies with dispersed ownership [36].

Under the Agency Theory perspective, Jain and Jamali [20] argued that concentrated owners are prone to stall any CSR investment employed by managers for entrenchment purposes. Furthermore, as the main shareholders are able to obtain the company's information through internal communication mechanisms, they are less willing to publicly expose their own company's performance [57]. However, as an exception, Jain and Jamali [20] also suggested that following a stakeholder logic, the substantial shareholders could support managers' decisions on CSR issues because of their long-term positive effect on corporate competitiveness and firm value [58]. In this line, Prado-Lorenzo et al. [59] associated firm reputation with the dominant shareholder's personal reputation and they concluded that when a dominant shareholder is interested in the company's long-term survival as well as in maintaining his or her own personal reputation, the firm will be more likely to adopt decisions aimed at improving its economic, social, and environmental performance. 
Ownership structure influences CSR disclosure in developing countries [60], although the empirical evidence is scarce, mostly due to the lack of data available to carry out this research. Most of this evidence is focused on relation-based countries and the results report differences in the sign of the effect depending on the kind of ownership structure analyzed (i.e., family ownership [61] and managerial ownership [18], among others). Ownership concentration was analyzed in Chinese companies $[62,63]$ and the findings were contrary to these results. While the former found that companies with a more concentrated ownership have more CSR disclosure, the latter suggested that the extent of CSR reporting is negatively influenced by ownership concentration. Evidence from other developing countries is also inconclusive (a positive effect in Malaysia [53]; a negative effect in Bangladesh [22]).

Our second hypothesis states:

Hypothesis 2 (H2): Firm-level CG mechanisms are determinants of the CSR disclosure practices in BRICS countries.

\subsection{Group-Level CG Mechanisms}

CG encompasses the process aimed at setting global objectives and monitoring their achievement [64]. Boards of directors are one of the available structural elements for ensuring the success of this process. These directors are the last in charge of a business' operating efficiency and their decisions are made considering the point of view of competitiveness, including that related to CSR issues [65]. The literature shows that CG structures have been associated with voluntary disclosures, including CSR information $[34,51,66]$.

As Jain and Jamali [20] asserted, boards represent mechanisms for monitoring managers to avoid agency conflicts, but also allow companies to consider multiple stakeholder interests in the process of managerial decision-making. Hence, boards' behaviors when CSR reporting is under study is explained from two approaches: Agency Theory (supervisory function), and Stakeholder Theory (managerial function). In addition, good management arguments $[67,68]$ also contribute to justifying why CG mechanisms at the group level can affect CSR disclosure decisions. In this sense, this last theoretical approach suggests that more effective boards are those which make the best decisions-in this case CSR disclosure-looking for an increase of financial performance.

Two CG mechanisms have normally been considered for assessing both the effectiveness in board decisions related to CSR reporting and the monitoring capability of boards: board size and board independence [69].

Board size has been considered as a crucial aspect of CG. However, its effect on CSR disclosure is controversial [70]. In accordance with Stakeholder Theory, large corporate boards could be representative of diverse interests [71]. From another point of view, Jensen [72] emphasized that a board with more directors is less likely to function effectively due to coordination, communication, or free-rider problems. Some authors have argued that the impact of board size depends on the efficiency of the decision-making process [5]. In this regard, Coles et al. [73] showed that larger boards are able to monitor business operations better than smaller ones, but they also indicated that when boards are too large the monitoring process becomes ineffective. Consequently, Mahmood et al. [74] suggested that there is not an ideal board size for all companies.

Empirical evidence on the influence of board size on the CSR reporting practices of companies from BRICS nations is very scarce. Ntim and Soobaroyen [36] identified a weak and positive association for non-financial firms listed on the Johannesburg Stock Exchange. Focusing on Chinese companies, References [75-77] reported that board size had a positive influence on CSR reporting. In another study concerning the effect of CG structure and strategic CSR on sustainability reporting quality in companies from the Asian-Pacific region, Amran et al. [11] showed an insignificant relationship. Empirical evidence from other developing countries supported a positive association (Pakistan $[74,78,79]$, Sri Lanka [80], Malaysia [51-53,81,82]) or revealed the lack of a statistically significant effect (Turkey [83,84]). 
Board independence is another aspect of CG that is frequently studied for its relevance. For Li et al. [50], one of the board's main roles is the monitoring of managers' activity on behalf of owners. According to this aim, this role could be developed by incorporating outside directors, since they are under less pressure from shareholders and managers than internal ones [69] and they usually have a greater expertise [57,59]. Thus, from Agency Theory, the literature suggests that increasing independent directors contributes to mitigating agency costs and improving the quality of board monitoring [54,55].

Consequently, the higher presence of directors who are less aligned to management usually encourages companies to engage in corporate voluntary disclosure in general, and in CSR disclosures in particular [85]. Likewise, it is suggested that a higher proportion of independent directors (1) usually translates into a greater transparency commitment and this, in turn, has a positive effect on the long-term firm value [86]; (2) not only ensures that companies are properly monitored and managed, but also contributes to enhancing corporate image [87].

In general, though most authors usually hypothesize a positive association between board independency and CSR disclosures, the empirical evidence is mixed. Again, few studies have focused on BRICS nations, either as a whole or separately. Among studies which found positive evidence are those conducted on a sample of companies from BRICS nations [50], on Chinese firms [62], on South African listed firms [36], and on Indian publicly listed companies [88]. Recently, Liu and Zhang [75] and Liao et al. [76] did not note that the proportion of independent directors in Chinese companies was a determinant variable in order to explain CSR disclosures. Nor did Amran et al. [11] find evidence in a sample with companies from the Asian-Pacific region. Looking at empirical evidence of firms from different developing countries, there is not a clear relationship—both positive results (Pakistan [74,79], Bangladesh [22], Turkey [83,84]) and non-significant effects (Sri Lanka [80], Pakistan [78]) have been found. The case of Malaysia is special since there are prior studies concluding that there is a positive link [53], a negative link [80], and studies which did not find a significant relation [51,52,82].

Considering the lack of consensus of prior evidence and the extant gap with respect to BRICS nations, our third hypothesis states:

Hypothesis 3 (H3): Group-level CG mechanisms are determinants of the CSR disclosure practices in BRICS countries.

\section{Data Sources and Methodology}

\subsection{Sample}

Our research is focused on BRICS countries (Brazil, Russia, India, China, and South Africa) because they are recognized internationally as the five emerging markets with the greatest potential to influence global economic and political spheres. Thus, the selection of companies from these BRICS countries is motivated by (i) the relevance of these emerging markets in the international economic environment; (ii) the particular way in which these countries have faced the recent financial crisis; (iii) the little attention paid to CSR disclosure in developing countries, and (iv) the existence of differences in CSR reporting strategies in their companies as well as their use of CG mechanisms when compared with those in a more developed context.

The sample used is composed of listed companies located in BRICS countries, whose CG and financial data were available in the ASSET4 Thomson Reuters database and whose CSR reports could be read. After performing this two-step selection process, the final sample included 281 companies as a representation of each country's best companies.

Then, the CSR disclosure practices carried out by each company was analyzed based on the information of their CSR/sustainability reports, their annual financial statements, and their integrated reports. Except for a few companies, most of these documents were directly downloaded from the Global Reporting Initiative website Considering the "disclosure precedent" argument [89] (which argues that firms have to maintain the same pattern of reporting because stakeholders' expectations 
depend on previous reporting), it is not necessary to contemplate a sequence of reports. Finally, in order to ensure the comparability of the reports considered, our sample is composed of the reports corresponding to the financial year 2012. A new version of GRI guidelines (4.0) was launched in May 2013. This new version implied changes in the content as well as in the level of adoption of the guidelines since there was no longer levels A, B, or C. Companies had until the end of 2015 to adopt this new version (GRI 4.0), but some of them continued with the GRI 3.1 version while others decided to adopt the GRI 4.0. This meant that from 2013 until 2016, there was not a unique version of the guidelines and thus the comparability of companies decreases.

\subsection{Variables}

Table 1 presents the information and references about how each dependent, independent, and control variable is measured.

\subsubsection{Dependent Variables: CSR Reporting Practices}

"CSR reporting complexity" is used as a dependent variable to evaluate the level of commitment assumed by each company concerning the disclosure of their social and environmental behaviors. This was elaborated following the index of Moneva et al. [90] based on the aggregation of four items (dummy variables). Consistent with Muñoz et al. [91], every firm is classified depending on the score obtained on the complexity of its CSR report as "opaque" (0 points), "pro-translucid" (1 point), "translucid" ( 2 points), "pro-transparent" ( 3 points), and "transparent" (4 points).

Table 1. Dependent, independent, and control variables.

\begin{tabular}{|c|c|c|c|}
\hline & \multicolumn{2}{|l|}{ Variables } & Measures \\
\hline \multirow[t]{2}{*}{$\begin{array}{l}\text { Dependent } \\
\text { variable }\end{array}$} & \multicolumn{2}{|c|}{ Corporate Social Responsibility (CSR) reporting complexity [90] } & $\begin{array}{l}\text { Index formed by: } \\
\text { CSR information in a report } \\
\text { GRI adoption } \\
\text { Getting a GRI “in accordance" level } \\
\text { Assurance of the CSR report }\end{array}$ \\
\hline & \multicolumn{2}{|l|}{ GRI levels [16] } & $\begin{array}{l}\text { 0-non-GRI application level } \\
\text { 1-GRI level C } \\
\text { 2-GRI level B } \\
\text { 3-GRI level A }\end{array}$ \\
\hline \multirow{4}{*}{$\begin{array}{l}\text { Independent } \\
\text { variables }\end{array}$} & \multirow{2}{*}{$\begin{array}{l}\text { Group-level corporate governance } \\
\text { (CG) mechanisms }\end{array}$} & Board size [76] & Number of directors \\
\hline & & Independent directors [88] & $\%$ of independent directors \\
\hline & Firm-level CG mechanisms & Reference shareholder* & Dummy variable $[26,59]$ \\
\hline & Institutional-level CG mechanism & & $\begin{array}{l}\text { GEI }[92,93] \text { : rule-based, family-based } \\
\text { or relation-based }\end{array}$ \\
\hline \multirow{6}{*}{$\begin{array}{l}\text { Control } \\
\text { variables }\end{array}$} & \multirow{3}{*}{ Organizational characteristics } & Size & Total assets $[11,51]$ \\
\hline & & Profitability & ROA $[16,35]$ \\
\hline & & International sales & Dummy variable [32] \\
\hline & \multicolumn{2}{|l|}{ CSR committee } & Dummy variable $[11,15]$ \\
\hline & \multicolumn{2}{|l|}{ Mandatory } & $\begin{array}{l}\text { Dummy variable [94]: } 0 \text { (Voluntary), } \\
1 \text { (Mandatory) }\end{array}$ \\
\hline & \multicolumn{2}{|l|}{ Industry sensitivity [95] } & ASSET 4 \\
\hline
\end{tabular}

* If the company is owned by a reference shareholder who has the majority of the voting rights, veto power or golden share; ** this is considered if there was any policy and regulation for sustainability and CSR reporting in 2012 regarding the listed companies. In our case, this was mandatory in Brazil, China, and South Africa. GEI: Governance Environment Index; ROA: Return on Assets.

Nevertheless, this CSR Index does not reflect the different GRI application levels. Therefore, another variable, "GRI level", was designed based on Rodríguez-Ariza et al. [16] to assess the scope of the CSR disclosure carried out by firms according to the GRI standards. 


\subsubsection{Corporate Governance Mechanism: Group, Firm, and Institutional Levels}

As discussed before, we focused our study on the group, firm, and institutional levels of CG mechanisms pointed out by Jain and Jamali [20]. Considering previous evidence in the field of CSR reporting, we selected the specific indicators for each kind of measure (see Table 1).

The board of directors has to make decisions, and a way to assure that these decisions have been taken considering all the perspectives comes as a result of an optimal composition. Between the different options to measure the group-level CG mechanisms, we focused on the efficacy of the composition of the boards of directors, and specifically on board size and the independence of directors because the previous literature has pointed these factors out as being the most determinant CG mechanisms.

One of the main roles of the board of directors is to solve potential conflicts of interest between shareholders and managers. Consequently, the presence of a reference shareholder is one of the most relevant characteristics of ownership which is undoubtedly going to have an influence on the company's strategic decisions [26]. Hence, it is the measure used for the firm-level CG mechanism. As a measure of institutional CG mechanisms, we used the Governance Environment Index (GEI) developed by $\mathrm{Li}$ and Filer [96]. This index considers five relevant aspects of each environment: political rights, rule of law, free press, the quality of accounting standards, and general trust levels. The procedure for obtaining GEI data is explained in detail in Li and Filer [96] This index shows the degree to which a society relies on a certain type of governance mechanism to govern social exchanges. In other words, it is an aggregate measure encompassing different institutional factors related to the political, legal, economic, and cultural aspects of the environment in which a company operates. According to the sign of this index [92], a society could be rule-based (if it received a positive GEI score), or non-rule-based (if it received a negative score). In order to make a distinction between those societies classified as non-rule-based, a cluster analysis was carried out by the introduction of trust variables. As a result, family-based and relation-based societies were differentiated [93]. Table 2 shows the GEI scores and their classification.

Table 2. GEI scores and classification of countries involved in the study.

\begin{tabular}{llllll}
\hline \multicolumn{2}{c}{ Relation-Based } & \multicolumn{2}{c}{ Family-Based } & \multicolumn{2}{c}{ Rule-Based } \\
\hline \multirow{3}{*}{ China } & & Russia & -4.34 & & \\
& -5.92 & Brazil & -2.06 & South & \multirow{2}{*}{3.11} \\
& & India & -0.85 & Africa & \\
\hline
\end{tabular}

Source: References [92,93].

\subsubsection{Control Variables}

Moreover, we included several control variables related to company characteristics, such as size [88,97], profitability [35,77,98], regulation [31], internationalization [32,33], and industry sensitivity [99] based on the previous literature.

Additionally, the existence of a CSR committee $[34,56,74]$ at the board level is a clear indication of the company's CSR engagement. Since one of this committee's functions is to ensure the quality of company sustainability disclosure, the existence of a CSR committee can be viewed as a sign of its commitment to the stakeholders $[11,15]$.

\subsection{Regression Model Proposed}

In accordance with the objectives proposed, we used ordinal regression models instead of other more complex statistical models due to (1) the low number of hypotheses and (2) the lack of variables that require more than one measure to be evaluated. In addition, multiple linear regression models have been frequently used to investigate the link between explanatory variables and CSR reporting $[11,26,30,70]$. We used Stata, version 12.0 for statistics. In order to consider whether 
institutional CG mechanisms significantly influence firm and group-level CG mechanisms, this variable helped us to break up the sample into three subsamples (relation-based, family-based, and rule-based).

So, the proposed model is (see Figure 1):

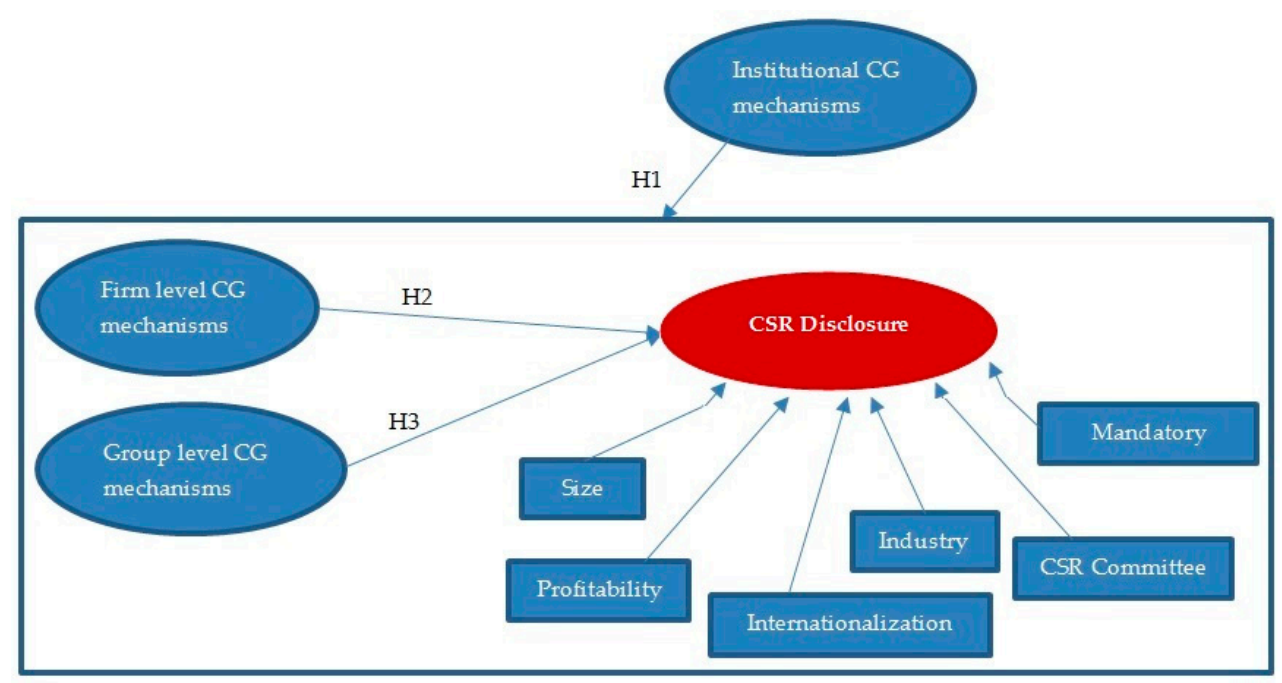

Figure 1. Map of the proposed hypotheses.

CSR disclosure $=\$ 1+\beta 2$ firm-level/group-level CG mechanisms $+\$ 3$ company size $+\$ 4$ profitability $+\$ 5$ internationalization $+\$ 6$ CSR committee $+\$ 7$ mandatory $+ß 8$ industry sensitivity $+\varepsilon$.

\section{Results and Discussion}

From Tables 3 and 4, the composition of the sample can be seen: $32.03 \%$ from South Africa, $27.05 \%$ from India, $16.73 \%$ from China, $15.65 \%$ from Brazil, and $8.54 \%$ from Russia. That is, the most represented country is South Africa and the least is Russia.

Table 3. Descriptive analysis (mean values) of the sample focused on the quantitative information.

\begin{tabular}{ccccccc}
\hline & Complete Sample & Brazil & China & India & Russia & South Africa \\
& $\mathbf{N = 2 8 1}$ & $\mathbf{N = 4 4}$ & $\boldsymbol{N}=\mathbf{4 7}$ & $\boldsymbol{N = 7 6}$ & $\boldsymbol{N = \mathbf { 2 4 }}$ & $\boldsymbol{N}=\mathbf{9 0}$ \\
\hline Total assets (millions) & 592.520 & 57.301 & 1066.461 & 724.523 & 2196.530 & 67.473 \\
ROA & 7.878 & 6.352 & 3.846 & 9.638 & 6.134 & 9.709 \\
International sales (millions) & 68.183 & 3.380 & 24.025 & 112.762 & 353.637 & 9.157 \\
Board size & 10.94 & 9.02 & 11.08 & 10.89 & 11.16 & 11.76 \\
Independent directors (\%) & 37.612 & 22.47 & 24.90 & 44.75 & 37.46 & 45.65 \\
\hline
\end{tabular}

Estimated data based on the information from ASSET4.

The descriptive analysis of the complete sample presents an overview of the firms analyzed and there are significant differences in the characteristics of the companies between countries. The larger size and the higher amount of international sales of Russian companies should, then, be pointed out. On the other hand, Brazilian and South African companies are revealed as the smallest in the sample considered. The most profitable companies are those from South Africa and India.

In relation to the size of the board of directors, the board does not present any significant variation among the countries. Most organizations have around 11 directors, except for Brazilian firms whose boards are smaller (around nine directors).

South African and Indian firms are characterized as having the largest percentage of independent members on their boards (around $45 \%$ of the directors are independent), while this percentage is smaller for Brazilian and Chinese companies (less than 25\%). This result disagrees with the corporate governance recommendations made by the Brazilian Code of Governance in 2009, which suggest that most directors should be independent. Nevertheless, our results are in accordance with the report by 
Li et al. [50] concerning the association between board independence and the GEI level of companies in more rule-based environments, which usually have more independent boards.

Table 4. Descriptive analysis of the sample focused on the qualitative information.

\begin{tabular}{ccccccc}
\hline & Complete Sample & Brazil & China & India & Russia & South Africa \\
& $\mathbf{N = 2 8 1}$ & $\mathbf{N = 4 4}$ & $\mathbf{N = 4 7}$ & $\mathbf{N = \mathbf { 7 6 }}$ & $\mathbf{N = \mathbf { 2 4 }}$ & $\mathbf{N = 9 0}$ \\
\hline Complexity of the CSR reporting & & & & & & \\
Opaque & $18.1 \%$ & $20.5 \%$ & $27.7 \%$ & $22.4 \%$ & $33.3 \%$ & $4.4 \%$ \\
Pro-translucid & $45.2 \%$ & $11.4 \%$ & $63.8 \%$ & $47.4 \%$ & $20.9 \%$ & $56.7 \%$ \\
Translucid & $7.8 \%$ & $11.4 \%$ & $4.3 \%$ & $1.3 \%$ & $12.5 \%$ & $12.2 \%$ \\
Pro-transparent & $13.2 \%$ & $22.7 \%$ & $0 \%$ & $6.6 \%$ & $33.3 \%$ & $15.6 \%$ \\
Transparent & $15.7 \%$ & $34.1 \%$ & $4.3 \%$ & $22.3 \%$ & $0 \%$ & $11.1 \%$ \\
\hline GRI level & & & & & & \\
A & $16.0 \%$ & $29.5 \%$ & $2.1 \%$ & $27.6 \%$ & $16.6 \%$ & $6.7 \%$ \\
B & $13.2 \%$ & $25 \%$ & $2.1 \%$ & $1.3 \%$ & $25 \%$ & $20 \%$ \\
C & $6.0 \%$ & $13.6 \%$ & $0 \%$ & $0 \%$ & $4.2 \%$ & $11.1 \%$ \\
Non-GRI & $64.8 \%$ & $31.8 \%$ & $95.8 \%$ & $71.1 \%$ & $54.2 \%$ & $62.2 \%$ \\
\hline Reference shareholder (\%) & 0.36 & 0.50 & 0.43 & 0.37 & 0.70 & 0.44 \\
\hline CSR committee (\%) & 0.61 & 0.75 & 0.30 & 0.47 & 0.33 & 0.88 \\
\hline
\end{tabular}

Estimated data based on the information from ASSET4.

In addition, the greater number of companies in which there is a reference shareholder is also reported for companies located in Russia and Brazil. It should be highlighted that $36 \%$ of the companies of the samples have a reference shareholder. As we considered this data as a representation of the ownership concentration, we deduce that a majority of the companies included in the sample have a non-concentrated ownership. Likewise, $61 \%$ of the companies included in the sample have a CSR committee. Nevertheless, this percentage is significantly lower for companies from China and Russia.

As to the dependent variable, it is important to highlight the lack of engagement with CSR disclosure shown by around $18 \%$ of the companies analyzed (51 of the 281). These findings support a positive association between the governance environment index and the companies' engagement with CSR reporting. Thus, companies from rule-based societies are more committed to CSR information disclosure and are less "opaque" [50], although it should be considered that companies in the rule-based country included in the sample have to mandatorily report. In this sense, Loprevite et al. [100] asserted that the introduction of mandatory regulations has a significant positive effect on corporate reporting, although not all researchers agree with this [101,102].

It is relevant to point out the low percentage of opaque firms in South Africa, with only $4 \%$ (four out of 90). Conversely, Russia and China have the highest percentages of opaque firms, with $33.3 \%$ and $27.7 \%$, respectively. Despite policies and regulations related to sustainability development in China, the low commitment of companies has been noted previously by other authors and most of them agree that CSR reporting is in its beginnings in China [36,49,77]. Likewise, the engagement of Russian companies contrasts with the behavior of other European companies which have to face significant transparency requirements. Despite the fact that $18.1 \%$ of companies do not report about CSR, the percentage of companies committed to CSR reporting is higher than the world mean value (according to Reference [9], this is $71 \%$ for N100) and lower than the mean value for developed countries.

Regarding transparency, $28.9 \%$ of the firms included in the sample are classified as pro-transparent or transparent. Brazil is the country which presents a higher number of companies classified as transparent, followed by India, which is consistent with the findings of Arrive and Feng [31].

On the other hand, considering only those companies that publish some kind of report $(81.9 \% ; 230$ out of the 281 companies in the sample), it was observed that those which prepare the report following the GRI guidelines were less (99) than those which did not follow this standard (131). This result suggests that the GRI standards are not used as much by companies in BRICS countries as in developed countries since, according to KMPG [103] in 2013, they are used in $74 \%$ of the CSR reports around the world. 
Among the studied companies, there is a relevant difference concerning the use or non-use of the GRI guidelines. In particular, while $85.7 \%$ of Brazilian companies which published a CSR report (30 of 35) used this standard as a reference and achieved an A, B, or C level, only $5.6 \%$ of Chinese firms disclosing CSR information preferred to follow the GRI guidelines (two out of 34). Interestingly, after Brazilian corporations, firms from Russia showed a higher tendency to follow the GRI recommendations- $68.75 \%$ of the 16 firms which published a report. Taking into account the companies which did so, the percentages of firms from Brazil and India that achieved an A adoption level are the highest. The case of Indian companies is particularly interesting since those which decided to adopt the GRI recommendations did this comprehensively and almost all of them achieved an A level.

Regarding the bivariate correlations reported in Table 5, it is highlighted that both CSR disclosure measures considered are highly correlated. Moreover, board size, the existence of a CSR committee, and the presence of a reference shareholder show a positive correlation with both CSR disclosure measures. Between the different levels of CG mechanisms, it necessary to point out that institutional CG mechanisms present a high correlation with group- and firm-level CG measures. This fact prompted our not being able to include this variable in our regressions due to collinearity problems. However, in order to test its effect, we used it to divide the sample.

Table 5. Bivariate correlations.

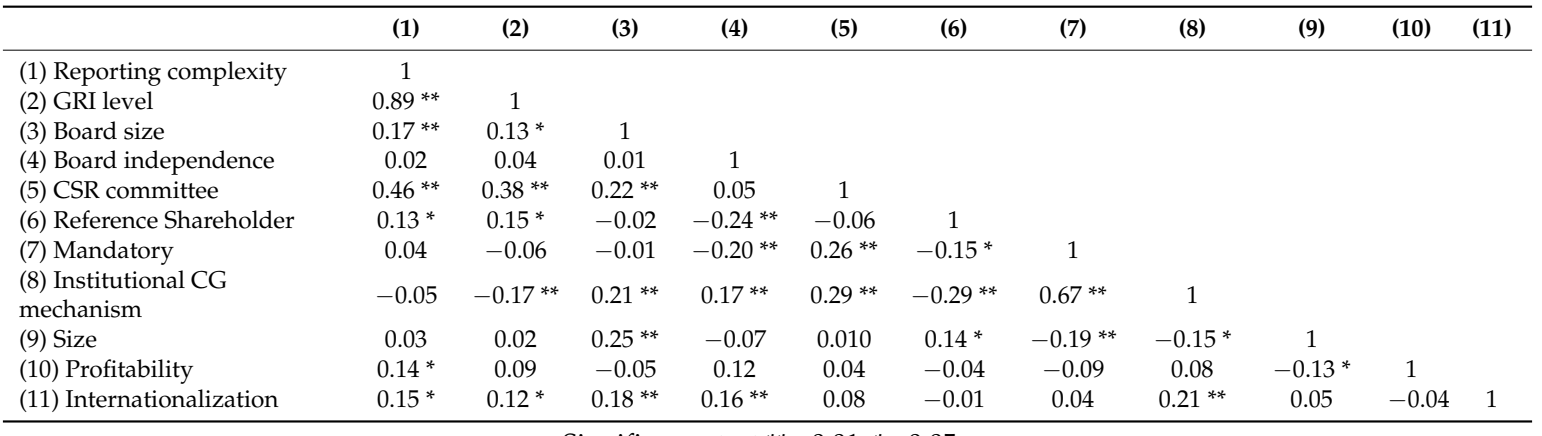

Significance test ${ }^{* *}<0.01,{ }^{*}<0.05$.

Additionally, board independence presents a negative correlation with the existence of a reference shareholder, which means "the higher the ownership concentration, the less the percentage of independent directors on the board". In contrast to the results of Chen and Jaggi [85] result, board independence also shows a significant negative correlation with the existence of CSR regulations. This finding could be explained by the higher emphasis placed on CSR regulations in those countries where the recommendations about the proportion of independent board directors are not implemented. Moreover, the results reveal that there is a higher probability of companies with larger boards having CSR committees.

The results from the statistical tests of the regressions carried out are presented in Tables 6 and 7.

The analysis of the results related to CSR reporting complexity (Table 6) show that the explanatory power varies between $18 \%$ (for the rule-based subsample) and $50 \%$ (for the family-based subsample). These R squared coefficients are not so high (particularly in the case of the rule-based subsample), but most of them are greater than the coefficients reported in the previous literature on this topic in emerging countries $[27,51,75,76]$.

Firm-level CG mechanisms (particularly ownership concentration) have no significant statistical effect on CSR reporting complexity for each subsample considered. In this line, most previous evidence in the context of emerging countries is focused on relation-based societies and the results are not conclusive since some indicate that companies with a less concentrated ownership are those with a more extensive CSR disclosure [22,63], while others note the contrary [53,62]. 
Table 6. Determinants of CSR reporting complexity.

\begin{tabular}{|c|c|c|c|c|c|c|c|c|}
\hline \multirow[b]{2}{*}{ Constant } & \multicolumn{2}{|c|}{ Complete Sample } & \multicolumn{2}{|c|}{$\begin{array}{c}\text { Family-Based } \\
\quad(N=144)\end{array}$} & \multicolumn{2}{|c|}{$\begin{array}{l}\text { Relation-Based } \\
\quad(N=47)\end{array}$} & \multicolumn{2}{|c|}{$\begin{array}{l}\text { Rule-Based } \\
(N=90)\end{array}$} \\
\hline & $-4.894^{* * *}$ & $-4.883^{* * *}$ & $-6.062 * * *$ & $-5.744^{* * *}$ & $-2.773 *$ & $-2.941 *$ & -2.138 & -2.181 \\
\hline Board size & 0.029 & - & $0.067^{+}$ & - & -0.019 & - & 0.006 & - \\
\hline Board independ. & 0.002 & - & 0.003 & - & $-0.023 *$ & - & 0.003 & - \\
\hline Ref. shareholder & - & 0.107 & - & 0.006 & - & 0.217 & - & -0.042 \\
\hline Size & $0.240^{* * *}$ & $0.254^{* * *}$ & $0.262^{* * *}$ & $0.287^{* * *}$ & $0.223^{* * *}$ & 0.187 * & 0.170 & 0.186 * \\
\hline Profitability & $0.043^{* * *}$ & $0.042^{* * *}$ & $0.060 * * *$ & $0.061^{* * *}$ & 0.025 & 0.020 & 0.016 & 0.015 \\
\hline Internationalization & $0.462^{* * *}$ & $0.481^{* * *}$ & $0.443 *$ & $0.496^{*}$ & 0.308 & 0.283 & $0.666^{*}$ & $0.682 *$ \\
\hline $\begin{array}{c}\text { Industry } \\
\text { sensitivity }\end{array}$ & 0.191 & 0.164 & 0.413 * & 0.401 * & $-0.374^{\dagger}$ & $-0.379^{\dagger}$ & -0.561 & -0.563 \\
\hline CSR committee & $0.977^{* * * *}$ & $0.999^{* * * *}$ & $1.235^{* * *}$ & $1.293 * * *$ & 0.341 & 0.371 & 0.249 & 0.243 \\
\hline Mandatory & $1.742 * * *$ & $1.722 * * *$ & $1.767 * * *$ & $1.644^{* * *}$ & - & - & - & - \\
\hline $\begin{array}{c}\text { Country } \\
\text { (controlled) }\end{array}$ & $* * *$ & $* * *$ & - & - & - & - & - & - \\
\hline$R^{2}$ & 0.393 & 0.391 & 0.500 & 0.488 & 0.433 & 0.382 & 0.180 & 0.177 \\
\hline
\end{tabular}

Significance test ${ }^{* * *}<0.005,{ }^{*}<0.05,{ }^{\dagger}<0.1$.

Table 7. Determinants of GRI level.

\begin{tabular}{|c|c|c|c|c|c|c|c|c|}
\hline \multirow[b]{2}{*}{ Constant } & \multicolumn{2}{|c|}{ Complete Sample } & \multicolumn{2}{|c|}{$\begin{array}{c}\text { Family-Based } \\
\qquad(N=144)\end{array}$} & \multicolumn{2}{|c|}{$\begin{array}{l}\text { Relation-Based } \\
\qquad(N=47)\end{array}$} & \multicolumn{2}{|c|}{$\begin{array}{l}\text { Rule-Based } \\
\qquad(N=90)\end{array}$} \\
\hline & $-4.097^{* * *}$ & $-4.181^{* * *}$ & $-5.749 * * *$ & $-5.625^{* * *}$ & -1.557 & -1.255 & $\begin{array}{c}-3.530 \\
*\end{array}$ & $-3.241^{+}$ \\
\hline Board size & 0.023 & - & $0.072^{+}$ & - & -0.016 & - & -0.026 & - \\
\hline Board independ. & 0.004 & - & 0.007 & - & -0.005 & - & 0.001 & - \\
\hline Ref. shareholder & - & -0.048 & - & -0.212 & - & 0.231 & - & 0.007 \\
\hline Profitability & $0.037^{* * *}$ & $0.038^{* * *}$ & $0.047^{* * *}$ & $0.050 * * *$ & 0.013 & 0.011 & 0.023 & 0.022 \\
\hline Internationalization & $0.421^{* * *}$ & $0.447^{* * *}$ & $0.320^{\dagger}$ & $0.389 *$ & 0.177 & 0.187 & $0.781 *$ & $0.781 *$ \\
\hline $\begin{array}{c}\text { Industry } \\
\text { sensitivity }\end{array}$ & $0.354 *$ & $0.348 *$ & $0.548^{* *}$ & $0.574^{* * *}$ & -0.180 & -0.217 & -0.178 & -0.162 \\
\hline CSR committee & $0.662^{* * *}$ & $0.671^{* * *}$ & $0.850^{* * *}$ & $0.904^{* * *}$ & -0.070 & -0.047 & 0.242 & 0.200 \\
\hline Mandatory & $1.460 * * *$ & $1.438^{* * *}$ & $1.815^{* * *}$ & $1.712 * * *$ & - & - & - & - \\
\hline
\end{tabular}

Significance test ${ }^{* * *}<0.005,{ }^{*}<0.05,{ }^{\dagger}<0.1$.

Nevertheless, group-level CG mechanisms are revealed as determinants of CSR reporting complexity for companies in relation-based and family-based countries. Yet, it should be pointed out that the concrete mechanisms which affect CSR reporting complexity vary. In the case of firms from family-based environments, the strategy of reporting will be more complex for those companies with larger boards. The curvilinear relationship has been tested, but the results suggest that there is a linear relationship for all subsamples. These results represent a contribution to the lack of previous empirical evidence in family-based environments. This scarcity could be explained by the limited availability of data in some countries (i.e., Russia) and the absence of results for each individual country included in cross-cultural studies (i.e., Brazil). Nevertheless, research focused on other family-based environments, such as Turkey [83,84], has suggested that board size has no influence on CSR reporting practices.

However, the higher the percentage of independent members, the lower the complexity of the CSR reporting practices in organizations from a relation-based environment. Previous evidence in this regard shows no significant [75,76] or positive effect [62] in Chinese companies, although Esa and Ghazali [81] found a negative impact in Malaysian companies, which also belong to a relation-based environment.

Any firm- or group-level CG mechanism has a statistically significant effect on the complexity of CSR disclosure practices for companies in rule-based countries. One of the main reasons behind this behavior is related to the fact that companies of the country analyzed (South Africa) have to 
mandatorily report on social and environmental issues. This greatly conditions the CSR disclosure practices carried out.

From the study of the GRI level (Table 7), the loss of predictive power in almost all cases except for the rule-based environment must be pointed out, due to the differences found in the degree of adoption in each country. This effect is higher in case of a relation-based environment, which is explained by the low number of companies that prepare their reports following the GRI guidelines (see Table 4). Some institutional environments show a statistically significant effect of firm-level CG mechanisms; however, for family-based environments, group-level CG mechanisms present a positive influence of the adoption of a higher GRI level (in particular, board size). As is seen in Table 7, practically no variable included in our study is a determinant of achieving a GRI level in companies from relation-based societies. Only company size and internationalization are determinants of this adoption in rule-based firms.

The existence of a CSR committee has a positive significant effect on both CSR reporting practices in the complete sample as well as in firms from family-based societies. As was discussed by Adnan et al. [19], the existence of a committee in charge of sustainability issues shows that this company is concerned about its socially and environmentally friendly actions. However, no significant impact is reported in companies from relation and rule-based environments. Although the reasons that could explain these results seem to be very contradictory (see the difference in the percentage of companies from each country that have a CSR committee), it is necessary to point out that reporting is mandatory in countries involved in the two GEI considered. There is a lack of previous empirical evidence in this respect since most research in countries in which CSR reporting is mandatory does not include this variable in its analyses. If companies have to report about CSR issues, the existence of this committee seems to have no impact on the complexity of their CSR disclosure policies or on the adoption of GRI standards.

Company size shows a significant impact on the CSR report's level of complexity as well as on the degree of GRI adoption, even though the level varies depending on the institutional environment considered. Consistent with Chatterjee and Mir [97], the larger the company, the more visible its stakeholders and the higher the expectations for bearing the costs resulting from their political or lobbying actions. Thus, it is reasonable for bigger firms to find more advantages in CSR reporting than smaller ones. Nevertheless, profitability does not always present a significant impact, but rather only if the complete sample or family-based subsample is considered. This evidence is not in line with the results of Kansal et al. [27]. They found no statistically significant effect in Indian companies. In this sense, one of the main reasons behind this lack of a significant effect could be linked to the existence of mandatory reporting.

Contrary to assumptions made under Legitimacy Theory [104], but consistent with the results of Chan and Welford [105], relation-based countries show an inverse and significant relationship between CSR reporting and the industry's exposure to environment-related risks. In firms belonging to rule-based countries, international activity is reported as a unique variable which significantly affects the CSR reporting complexity.

The differences found concerning the significant determinants of CSR reporting among companies from a family-based environment or not lead us to take an opposite point of view from Reverte [26], who argued that the limited effect of the institutional environment on CSR strategies is a consequence of increasingly globalized stock markets.

In addition, it should be pointed out that the goodness-of-fit coefficients in the case of rule-based environments for both models (the CSR reporting complexity and the GRI level) are lower than those for the rest of the institutional environments. This is explained by the fact that the regulation in South Africa obliges companies to report following the integrated reporting framework.

If the results obtained from this research are compared with the empirical evidence in developed countries, we highlight that most evidence suggests a positive impact of the existence of a reference shareholder on specific CSR reporting practices (assurance [18], GRI [59]). That means that he/she 
is identified with the company and in a long-term relationship, so this encourages transparency and accountability. As to the group-level CG measures, we underscore that most CSR reporting practices are positively influenced by board size $[15,16,18,106]$, although some authors have pointed out the existence of a U-shaped relationship [17]. Regarding the presence of independent directors, most of the literature has suggested a non-significant impact of this variable [70], although some research has presented a positive influence $[69,86]$.

\section{Conclusions}

The aim of this research was to analyze how different levels of CG mechanisms affect companies' CSR reporting strategies in the context of emerging countries, since previous evidence suggests differences in these companies as compared to those in developed countries. There has been scarce empirical research on this topic, mainly due to the lack of data availability.

The research conducted shows how institutional differences among BRICS nations should be taken into account when an exhaustive analysis of CSR reporting determinants is carried out. In this sense, our outcomes show the effect of cultural and social settings on CSR reporting and shed light on the relevance of promoting the social and environmental awareness mechanisms surrounding companies in addition to developing CSR policies focused on corporations. Also, the influence of the institutional CG mechanism confirms the argument that the normative and cultural peculiarities of each environment require different analyses and answers. The divergences identified could be a response adapted to the cultural and normative environments, even among countries that a priori share certain economic features. In fact, this variable moderates the effect of most of the corporate characteristics and contextual and internal factors analyzed. Considering all these arguments, the main contribution of our research is to add more evidence to the Institutional Theory framework in the CSR reporting field.

Our findings suggest that future research in the area should consider the suitability of using measures of CSR disclosure not based exclusively on the level of adoption of GRI standards. This will be particularly relevant in future research focused on companies located in countries where such standards are not the main option guiding CSR reports, and further investigation should be carried out on this particular topic.

This last argument remarks again the need to establish appropriate legal mechanisms to ensure minimum commitments in transparency. In this sense, it has been observed that for those companies in family-based environments, the existence of legal imperatives of reporting about CSR issues has a positive impact on the adoption of more complex CSR reporting practices. This contributes to the debate about whether CSR reports should be regulated or not. It provides evidence that the regulation concerning CSR reporting does not always imply that companies only comply with what is legally established, since they at times go further in the adoption of more complex practices.

It must be pointed out that our findings support the appropriateness of separately studying the effect of CG mechanisms on CSR disclosure practices in developing countries since they are different from those achieved by research focused on developed countries. The first difference is found in most developed countries being included in the category of rule-based societies, and most of them reported on a voluntary basis in the period analyzed. Considering this, most research on the topic based on companies from developed countries could not analyze the institutional level of CG mechanisms.

The second difference is due to the non-significant effect of the firm-level CG mechanisms presented in this research. In this sense, previous evidence in developed countries suggests that firms with a more concentrated ownership will have more complex CSR reporting strategies. The third difference concerns group-level CG mechanisms. Empirical evidence in developed countries concludes that the presence of independent directors and board size have a positive influence on the CSR reporting strategy, as long as the boards are effective. Nevertheless, our results suggest that only board size has an impact on CSR reporting practices in relation-based countries. 
Our research also shows that determinant factors of voluntary CSR reporting are not explicative when the reporting is done on a mandatory basis. Considering the increasing regulation in several countries, future research should consider these results and more thoroughly analyze the case of each law; that is, identify which CSR reporting practices are mandatory in each country. Once this has been analyzed, the next step may be to go further into the analysis of the determinants of more complex CSR reporting practices in countries in which companies have to mandatorily report.

Our findings could be extrapolated to those companies from emerging countries which are close in their institutional environment, particularly those from family-based or relation-based environments, as well as close in the level of development to those included in our sample. However, the evidence from this research is not generalizable to developing or developed countries since the degree of engagement with CSR reporting practices analyzed significantly differs (especially for GRI adoption), and due to the fact that CG mechanisms are not equally effective and developed in the particular environment analyzed. In this regard, it is clear that further research in the field on mandatory CSR reporting should be conducted, since it seems that most countries are adopting this kind of policy despite the limitations pointed out by several researchers.

In addition, due to the sample composition, the companies analyzed are those that are the most transparent of each country, so the results should be interpreted considering that they do not reflect the complete reality of these countries. In addition, some limitations exist due to the lack of data availability at the time of study, which led to only two measures of group-level and one measure of firm-level CG mechanisms being included in the empirical analysis. In this sense, further research on this topic is recommended, considering the environment of developing countries, that analyzes other kinds of firm-level CG mechanisms such as family, managerial, or institutional ownership in order to see if there are also differences with respect to developed countries.

As another limitation, we need to mention that the CSR reporting practices of each company were assessed by their respective CSR/sustainability reports, although firms can also disclose this kind of information through their website, press releases, or social networks. Future research may consider disclosure practices in a broader way to allow a more complete analysis of these practices.

Finally, we would like to point out that further research should develop an equivalent index of CSR reporting complexity that allows the reflection the changes in the GRI guidelines (i.e., "in accordance" core or comprehensive levels), as well as other novelties in the field of CSR reporting.

Author Contributions: Conceptualization, M.M.M.R. and B.E.P.; methodology and formal analysis, M.M.M.R. and D.M.M.; writing—original draft preparation, M.M.M.R., D.M.M., B.E.P.; writing—review and editing, M.M.M.R., D.M.M., B.E.P.; supervision, B.E.P.

Acknowledgments: We would like to acknowledge the support given by the Cátedra de Responsabilidad Social of the University of Seville to this research.

Conflicts of Interest: The authors declare no conflict of interest.

\section{References}

1. Aguinis, H.; Glavas, A. What we know and don't know about corporate social responsibility: A review and research agenda. J. Manag. 2012, 38, 932-968. [CrossRef]

2. Elkington, J. Governance for sustainability. Corp. Gov. 2006, 14, 522-529. [CrossRef]

3. Du, S.; Bhattacharya, C.B.; Sen, S. Maximizing business returns to corporate social responsibility (CSR): The role of CSR communication. Int. J. Manag. Rev. 2010, 12, 8-19. [CrossRef]

4. Bushman, R.; Piotroski, J.D.; Smith, A.J. What determines corporate transparency? J. Account. Res. 2004, 42, 207-252. [CrossRef]

5. Dienes, D.; Velte, P. The impact of supervisory board composition on CSR reporting. Evidence from the German two-tier system. Sustainability 2016, 8, 63. [CrossRef]

6. Crowther, D. Corporate reporting, stakeholders and the internet: Mapping the new corporate landscape. Urban Stud. 2000, 37, 1837-1848. [CrossRef] 
7. Ihlen, Ø.; Bartlett, J.; May, S. The Handbook of Communication and Corporate Social Responsibility, 1st ed.; John Wiley \& Sons: Hoboken, NJ, USA, 2011; ISBN 978-1-444-33634-4.

8. Jensen, J.C.; Berg, N. Determinants of Traditional Sustainability Reporting Versus Integrated Reporting. An Institutionalist Approach. Bus. Strategy Environ. 2012, 21, 299-316. [CrossRef]

9. KPMG. The KPMG Survey of Corporate Responsibility Reporting 2017; KPMG International Global Sustainability Services: Amsterdam, The Netherlands, 2017; Available online: https:/ /home.kpmg.com/content/dam/ $\mathrm{kpmg} /$ campaigns/csr/pdf/CSR_Reporting_2017.pdf (accessed on 16 October 2018).

10. Baskin, J. Corporate responsibility in emerging markets. J. Corp. Citizensh. 2006, 24, 29-47. [CrossRef]

11. Amran, A.; Lee, S.P.; Devi, S.S. The influence of governance structure and strategic corporate social responsibility toward sustainability reporting quality. Bus. Strategy Environ. 2014, 23, 217-235. [CrossRef]

12. Fifka, M. Corporate responsibility reporting and its determinants in comparative perspective-a review of the empirical literature and a meta-analysis. Bus. Strategy Environ. 2013, 22, 1-35. [CrossRef]

13. Dienes, D.; Sassen, R.; Fischer, J. What are the Drivers of Sustainability Reporting? A Systematic Review. Sustain. Account. Manag. Policy J. 2016, 7, 154-189. [CrossRef]

14. Ali, W.; Frynas, J.G.; Mahmood, Z. Determinants of corporate social responsibility (CSR) disclosure in developed and developing countries: A literature review. Corp. Soc. Responsib. Environ. Manag. 2017, 24, 273-294. [CrossRef]

15. Michelon, G.; Parbonetti, A. The effect of corporate governance on sustainability disclosure. J. Manag. Gov. 2012, 16, 477-509. [CrossRef]

16. Rodríguez-Ariza, L.; Frias, J.V.; García, R. El consejo de administración y las memorias de sostenibilidad. Revista de Contabilidad-Span. Account. Rev. 2014, 17, 5-16. [CrossRef]

17. Martínez-Ferrero, J.; García-Sánchez, I.M. Sustainability assurance and assurance providers: Corporate governance determinants in stakeholder-oriented countries. J. Manag. Organ. 2017, 23, 647-670. [CrossRef]

18. Miras, M.M.; Di Pietra, R. Corporate Governance mechanisms as drivers that enhance the credibility and usefulness of CSR disclosure. J. Manag. Gov. 2018, 22, 565-588. [CrossRef]

19. Adnan, S.M.; Hay, D.; Van Staden, C.J. The influence of culture and corporate governance on corporate social responsibility disclosure: A cross country analysis. J. Clean. Prod. 2018, 198, 820-832. [CrossRef]

20. Jain, T.; Jamali, D. Looking inside the Black Box: The Effect of Corporate Governance on Corporate Social Responsibility. Corp. Gov. 2016, 24, 253-273. [CrossRef]

21. Belal, A.R.; Momin, M. Corporate social reporting (CSR) in emerging economies: A review and future direction. In Research in Accounting in Emerging Economies-Accounting in Emerging Countries; Tsamenyi, M., Uddin, S., Eds.; Emerald: Bingley, UK, 2009; pp. 119-143. ISBN 978-1-84950-625-0.

22. Khan, A.; Muttakin, M.B.; Siddiqui, J. Corporate Governance and Corporate Social Responsibility Disclosures: Evidence from an Emerging Economy. J. Bus. Ethics 2013, 114, 207-223. [CrossRef]

23. Adams, C.A. Internal organisational factors influencing corporate social and ethical reporting. Account. Audit. Account. J. 2002, 15, 223-250. [CrossRef]

24. Claessens, S.; Yurtoglu, B.B. Corporate governance in emerging markets: A survey. Emerg. Mark. Rev. 2013, 15, 1-33. [CrossRef]

25. Fan, J.P.; Wei, K.J.; Xu, X. Corporate finance and governance in emerging markets: A selective review and an agenda for future research. J. Corp. Financ. 2011, 17, 207-214. [CrossRef]

26. Reverte, C. Determinants of corporate social responsibility disclosure ratings by Spanish listed firms. J. Bus. Eth. 2009, 88, 351-366. [CrossRef]

27. Kansal, M.; Joshi, M.; Batra, G.S. Determinants of corporate social responsibility disclosures: Evidence from India. Adv. Account. 2014, 30, 217-229. [CrossRef]

28. Sweeney, L.; Coughlan, J. Do different industries report corporate social responsibility differently? An investigation through the lens of stakeholder theory. J. Mark. Commun. 2008, 14, 113-124. [CrossRef]

29. Lattemann, C.; Fetscherin, M.; Alon, I.; Li, S.; Schneider, A.M. CSR communication intensity in Chinese and Indian multinational companies. Corp. Gov. 2009, 17, 426-442. [CrossRef]

30. Miras, M.M.; Escobar, B. Does the Institutional Environment affect CSR Disclosure? The Role of Governance. Rev. Adm. Empres. 2016, 56, 641-654. [CrossRef]

31. Arrive, J.T.; Feng, M. Corporate social responsibility disclosure: Evidence from BRICS nations. Corp. Soc. Responsib. Environ. Manag. 2018, 25, 920-927. [CrossRef] 
32. Chapple, W.; Moon, J. Corporate social responsibility (CSR) in Asia a seven-country study of CSR web site reporting. Bus. Soc. 2005, 44, 415-441. [CrossRef]

33. Araya, M. Exploring Terra Incognita: Non-financial Reporting in Latin America. J. Corp. Citizensh. 2006, 21, 25-38. [CrossRef]

34. Haniffa, R.M.; Cooke, T.E. The impact of culture and governance on corporate social reporting. J. Account. Public Policy 2005, 24, 391-430. [CrossRef]

35. Li, Q.; Luo, W.; Wang, Y.; Wu, L. Firm performance, corporate onwnership, and corporate social responsibility disclosure in China. Bus. Eth. A Eur. Rev. 2013, 22, 159-173. [CrossRef]

36. Ntim, C.G.; Soobaroyen, T. Corporate Governance and Performance in Socially Responsible Corporations: New Empirical Insights from a Neo-Institutional Framework. Corp. Gov. 2013, 21, 468-494. [CrossRef]

37. Aguilera, R.V.; Desender, K.; Bednar, M.K.; Lee, J.H. Connecting the dots: Bringing external corporate governance into the corporate governance puzzle. Acad. Manag. Ann. 2015, 9, 483-573. [CrossRef]

38. Di Maggio, P.J.; Powell, W.W. The iron cage revisited institutional isomorphism and collective rationality in organizational fields. Am. Sociol. Rev. 1983, 48, 147-160. [CrossRef]

39. Baughn, C.C.; Bodie, N.L.; McIntosh, J.C. Corporate Social and Environmental Responsibility in Asian Countries and Other Geographical Regions. Corp. Soc. Responsib. Environ. Manag. 2007, 14, 189-205. [CrossRef]

40. Ferri, L.M. The influence of the institutional context on sustainability reporting. A cross-national analysis. Soc. Responsib. J. 2017, 13, 24-47. [CrossRef]

41. Freeman, R.E. Strategic Management: A Stakeholder Approach; Pitman: Boston, MA, USA, 1984; ISBN 978-0273019138.

42. Orij, R. Corporate social disclosures in the context of national cultures and stakeholder theory. Account. Audit. Account. J. 2010, 23, 868-889. [CrossRef]

43. Deegan, C. The legitimising effect of social and environmental disclosures-A theoretical foundation. Account. Audit. Account. J. 2002, 15, 282-311. [CrossRef]

44. Clarkson, P.M.; Overell, M.B.; Chapple, L. Environmental reporting and its relation to corporate environmental performance. Abacus 2011, 47, 27-60. [CrossRef]

45. Campbell, J.L. Why would corporations behave in socially responsible ways? An institutional theory of corporate social responsibility. Acad. Manag. Rev. 2007, 32, 946-967. [CrossRef]

46. Aguilera, R.V.; Jackson, T. The cross-national diversity of corporate governance: Dimensions and determinants. Acad. Manag. Rev. 2003, 28, 447-466. [CrossRef]

47. Luoma, P.; Goddstein, J. Stakeholders and corporate boards: Institutional influences on board composition and structure. Acad. Manag. J. 1999, 42, 553-563.

48. Chiu, T.K.; Wang, Y.H. Determinants of social disclosure quality in Taiwan: An application of stakeholder theory. J. Bus. Eth. 2015, 129, 379-398. [CrossRef]

49. Alon, I.; Lattemann, C.; Fetscherin, M.; Li, S.; Schneider, A.M. Usage of Public Corporate Communications of Social Responsibility in Brazil, Russia, India and China (BRIC). Int. J. Emerg. Mark. 2010, 5, 6-22. [CrossRef]

50. Li, S.; Fetscherin, M.; Alon, I.; Lattemann, C.; Yeh, K. Corporate social responsibility in emerging markets: The importance of the Governance Environment. Manag. Int. Rev. 2010, 50, 635-654. [CrossRef]

51. Said, R.; Zainuddin, Y.H.; Haron, H. The relationship between corporate social responsibility disclosure and corporate governance characteristics in Malaysian public listed companies. Soc. Responsib. J. 2009, 5, 212-226. [CrossRef]

52. Haji, A.A. Corporate social responsibility disclosures over time: Evidence from Malaysia. Manag. Audit. J. 2013, 28, 647-676. [CrossRef]

53. Esa, E.; Zahari, A.R. Corporate social responsibility: Ownership structures, board characteristics \& the mediating role of board compensation. Procedia Econ. Financ. 2016, 35, 35-43. [CrossRef]

54. Jensen, M.C.; Meckling, W.H. Theory of the firm: Managerial behavior, agency costs and ownership structure. J. Financ. Econ. 1976, 3, 305-360. [CrossRef]

55. Fama, E.F.; Jensen, M.C. Separation of ownership and control. J. Law Econ. 1983, 26, 301-326. [CrossRef]

56. Ullmann, A.A. Data in search of a theory: A critical examination of the relationships among social performance, social disclosure, and economic performance of US firms. Acad. Manag. Rev. 1985, 10, 540-557.

57. Hu, K.H.; Lin, S.J.; Hsu, M.F. A Fusion Approach for Exploring the Key Factors of Corporate Governance on Corporate Social Responsibility Performance. Sustainability 2018, 10, 1582. [CrossRef] 
58. Barnett, M.L. Stakeholder influence capacity and the variability of financial returns to corporate social responsibility. Acad. Manag. Rev. 2007, 32, 794-816. [CrossRef]

59. Prado-Lorenzo, J.M.; Gallego-Alvarez, I.; Garcia-Sanchez, I.M. Stakeholder engagement and corporate social responsibility reporting: The ownership structure effect. Corp. Soc. Responsib. Environ. Manag. 2009, 16, 94-107. [CrossRef]

60. Rizk, R.; Dixon, R.; Woodhead, A. Corporate social and environmental reporting: A survey of disclosure practices in Egypt. Soc. Responsib. J. 2008, 4, 306-323. [CrossRef]

61. Panwar, R.; Paul, K.; Nybakk, E.; Hansen, E.; Thompson, D. The legitimacy of CSR actions of publicly traded companies versus family-owned companies. J. Bus. Eth. 2014, 125, 481-496. [CrossRef]

62. Huafang, X.; Jianguo, Y. Ownership structure, board composition and corporate voluntary disclosure: Evidence from listed companies in China. Manag. Audit. J. 2007, 22, 604-619. [CrossRef]

63. Zheng, L.; Balsara, N.; Huang, H. Regulatory pressure, blockholders and corporate social responsibility (CSR) disclosures in China. Soc. Responsib. J. 2014, 10, 226-245. [CrossRef]

64. Maier, S. How Global Is Good Corporate Governance; Ethical Investment Research Services: London, UK, 2005; Available online: www.eiris.org/files/research\%20publications/howglobalisgoodcorpgov05.pdf (accessed on 10 October 2018).

65. Hung, H. Directors' roles in corporate social responsibility: A stakeholder perspective. J. Bus. Eth. 2011, 103, 385-402. [CrossRef]

66. Velte, P. Does board composition have an impact on CSR reporting. Probl. Perspect. Manag. 2017, 15, 19-35. [CrossRef]

67. Waddock, S.A.; Graves, S.B. The corporate social performance-financial performance link. Strateg. Manag. J. 1997, 18, 303-319. [CrossRef]

68. Brennan, N. Boards of directors and firm performance: Is there an expectations gap? Corp. Gov. 2006, 14, 577-593. [CrossRef]

69. Hussain, N.; Rigoni, U.; Orij, R.P. Corporate Governance and Sustainability Performance: Analysis of Triple Bottom Line Performance. J. Bus. Eth. 2018, 149, 411-432. [CrossRef]

70. Giannarakis, G. Corporate governance and financial characteristic effects on the extent of corporate social responsibility disclosure. Soc. Responsib. J. 2014, 10, 569-590. [CrossRef]

71. Hillman, A.J.; Keim, G.D. Shareholder value, stakeholder management, and social issues: What's the bottom line? Strateg. Manag. J. 2001, 22, 125-139. [CrossRef]

72. Jensen, M.C. The modern industrial revolution, exit, and the failure of internal control systems. J. Financ. 1993, 48, 831-880. [CrossRef]

73. Coles, J.L.; Daniel, N.D.; Naveen, L. Boards: Does one size fit all? J. Financ. Econ. 2008, 87, 329-356. [CrossRef]

74. Mahmood, Z.; Kouser, R.; Ali, W.; Ahmad, Z.; Salman, T. Does corporate governance affect sustainability disclosure? A mixed methods study. Sustainability 2018, 10, 207. [CrossRef]

75. Liu, X.; Zhang, C. Corporate governance, social responsibility information disclosure, and enterprise value in China. J. Clean. Prod. 2017, 142, 1075-1084. [CrossRef]

76. Liao, L.; Lin, T.P.; Zhang, Y. Corporate board and corporate social responsibility assurance: Evidence from China. J. Bus. Eth. 2018, 150, 211-225. [CrossRef]

77. Sial, M.S.; Zheng, C.; Khuong, N.V.; Khan, T.; Usman, M. Does firm performance influence corporate social responsibility reporting of Chinese listed companies? Sustainability 2018, 10, 2217. [CrossRef]

78. Majeed, S.; Aziz, T.; Saleem, S. The effect of corporate governance elements on corporate social responsibility (CSR) disclosure: An empirical evidence from listed companies at KSE Pakistan. Int. J. Financ. Stud. 2015, 3, 530-556. [CrossRef]

79. Lone, E.J.; Ali, A.; Khan, I. Corporate governance and corporate social responsibility disclosure: Evidence from Pakistan. Corp. Gov. Int. J. Bus. Soc. 2016, 16, 785-797. [CrossRef]

80. Shamil, M.M.; Shaikh, J.M.; Ho, P.L.; Krishnan, A. The influence of board characteristics on sustainability reporting: Empirical evidence from Sri Lankan firms. Asian Rev. Account. 2014, 22, 78-97. [CrossRef]

81. Esa, E.; Ghazali, N.A.M. Corporate social responsibility and corporate governance in Malaysian government linked companies. Corp. Gov. Int. J. Bus. Soc. 2012, 12, 292-305. [CrossRef]

82. Janggu, T.; Darus, F.; Zain, M.M.; Sawani, Y. Does good corporate governance lead to better sustainability reporting? An analysis using structural equation modelling. Procedia Soc. Behav. Sci. 2014, 145, 138-145. [CrossRef] 
83. Sahin, K.; Basfirinci, C.S.; Ozsalih, A. The impact of board composition on corporate financial and social responsibility performance: Evidence from public-listed companies in Turkey. Afr. J. Bus. Manag. 2011, 5, 2959-2978. [CrossRef]

84. Kiliç, M.; Kuzey, C.; Uyar, A. The impact of ownership and board structure on Corporate Social Responsibility (CSR) reporting in the Turkish banking industry. Corp. Gov. 2015, 15, 357-374. [CrossRef]

85. Chen, C.J.P.; Jaggi, B. Association between independent non-executive directors, family control and financial disclosures in Hong Kong. J. Account. Public Policy 2000, 19, 285-310. [CrossRef]

86. Jizi, M.; Salama, A.; Dixon, R.; Stratling, R. Corporate governance and corporate social responsibility disclosure: Evidence from the US Banking Sector. J. Bus. Eth. 2014, 125, 601-615. [CrossRef]

87. Webb, E. An examination of socially responsible firms' board structure. J. Manag. Gov. 2004, 8, $255-277$. [CrossRef]

88. Muttakin, M.B.; Subramaniam, N. Firm ownership and board characteristics: Do they matter for corporate social responsibility disclosure of Indian companies? Sustain. Account. Manag. Policy J. 2015, 6, 138-165. [CrossRef]

89. Pistoni, A.; Songini, L.; Bavagnoli, F. Integrated Reporting Quality: An Empirical Analysis. Corp. Soc. Responsib. Environ. Manag. 2018, 25, 489-507. [CrossRef]

90. Moneva, J.M.; Rivera-Lirio, J.M.; Muñoz-Torres, M.J. The corporate stakeholder commitment and social and financial performance. Ind. Manag. Data Syst. 2007, 107, 84-102. [CrossRef]

91. Muñoz, M.J.; Rivera, J.M.; Moneva, J.M. Evaluating sustainability in organisations with a fuzzy logic approach. Ind. Manag. Data Syst. 2008, 108, 829-841. [CrossRef]

92. Li, S. Managing International Business in Relation-Based versus Rule-Based Countries; Business Expert Press: New York, NY, USA, 2009; ISBN 978-1-60649-084-6.

93. Wu, J.; Li, S.; Samsell, D. Why some countries trade more, some trade less, some trade almost nothing: The effect of the governance environment on trade flows. Int. Bus. Rev. 2012, 21, 225-238. [CrossRef]

94. KPMG. Carrots and Sticks. Sustainability Reporting Policies Worldwide-Today's Best Practice, Tomorrow's Trends; KPMG International Global Sustainability Services: Amsterdam, The Netherlands, 2013; Available online: https: / www.globalreporting.org/resourcelibrary/Carrots-and-Sticks.pdf (accessed on 8 March 2017).

95. Birkey, R.; Michelon, G.; Patten, D.M.; Sankara, J. Does assurance on CSR reporting enhance environmental reputation? An examination in the US context. Account. Forum 2016, 40, 143-152. [CrossRef]

96. Li, S.; Filer, L. The effects of the governance environment on the choice of investment mode and the strategic implications. J. World Bus. 2007, 42, 80-98. [CrossRef]

97. Chatterjee, B.; Mir, M.Z. The current status of environmental reporting by Indian companies. Manag. Audit. J. 2008, 23, 609-629. [CrossRef]

98. Lu, F.; Kozak, R.; Toppinen, A.; D'Amato, D.; Wen, Z. Factors influencing levels of CSR disclosure by forestry companies in China. Sustainability 2017, 9, 1800. [CrossRef]

99. Goncalves, R.; Medeiros, O.; Weffort, E.; Niyama, J. A social disclosure index for assessing social programs in Brazilian listed firms. In Research in Accounting in Emerging Economies-Accounting in Latin America; De Araujo, C., Frezatti, F., Eds.; Emerald: Bingley, UK, 2014; pp. 75-103. ISBN 978-1-78441-068-1.

100. Loprevite, S.; Ricca, B.; Rupo, D. Performance Sustainability and Integrated Reporting: Empirical Evidence from Mandatory and Voluntary Adoption Contexts. Sustainability 2018, 10, 1351. [CrossRef]

101. KPMG. The KPMG Survey of Corporate Responsibility Reporting 2015; KPMG International Global Sustainability Services: Amsterdam, The Netherlands, 2015; Available online: https:/ /home.kpmg.com/xx/en/home/ insights/2015/11/kpmg-international-survey-of-corporate-responsibility-reporting-2015.html (accessed on 16 October 2018).

102. Mobus, J.L. Mandatory environmental disclosures in a legitimacy theory context. Account. Audit. Account. J. 2005, 18, 492-517. [CrossRef]

103. Miras-Rodríguez, M.M.; Carrasco-Gallego, A.; Escobar-Pérez, B. Has the CSR engagement of electrical companies had an effect on their performance? A closer look at the environment. Bus. Strategy Environ. 2015, 24, 819-835. [CrossRef]

104. Branco, M.C.; Rodrigues, L.L. Factors influencing social responsibility disclosure by Portuguese companies. J. Bus. Eth. 2008, 83, 685-701. [CrossRef] 
105. Chan, J.H.; Welford, R. Assessing Corporate Environmental Risk in China: An Evaluation of Reporting Activities of Hong Kong Listed Enterprises. Corp. Soc. Responsib. Environ. Manag. 2005, 12, 88-104. [CrossRef]

106. Frias-Aceituno, J.V.; Rodriguez-Ariza, L.; Garcia-Sanchez, I.M. The Role of the Board in the Dissemination of Integrated Corporate Social Reporting. Corp. Soc. Responsib. Environ. Manag. 2013, 20, 219-233. [CrossRef] 